\title{
Daya Kecambah Kabesak (Acacia Leucophloea) dan Asam Jawa (Tamarindus Indica) Menggunakan Variasi Bahan dan Waktu Perendaman
}

\author{
Arnold Christian Hendrik ${ }^{\mathrm{a}}$, Agus Maramba Meha ${ }^{\mathrm{b}}$ \\ a Pendidikan Biologi, Universitas Kristen Artha Wacana, Kupang-NTT, Indonesia, email: Arnold_hendrik@yahoo.co.id \\ ${ }^{b}$ Pendidikan Biologi, Universitas Kristen Artha Wacana, Kupang-NTT, Indonesia, email: agusmaramba@yahoo.com
}

\section{Article Info}

Article history:

Received 23 Januari 2020

Received in revised form 25 Juni 2020

Accepted 6 Juli 2020

DOI:

https://doi.org/10.32938/sc.v5i03.980

Keywords:

Acacia Leucophloea

Tamarindus Indica

Daya Kecambah

\section{Abstrak}

Pembudidayaan jenis tanaman kehutanan lokal perlu pengetahuan mengenai teknik perkecambahan yang tepat, untuk memperoleh semai secara cepat dalam jumlah banyak dengan kualitas semai yang baik. Tanaman Kabesak (Acacia leucophloea) dan asam jawa (Tamarindus indica) dipilih untuk penelitian ini karena merupakan tanaman yang memiliki manfaat penting secara ekonomis dan ekologis bagi masyarakat lokal. Tujuan penelitian yakni mengetahui penggunaan variasi bahan perendaman dan waktu perendaman yang paling baik dalam meningkatkan perkecambahan Kabesak dan Asam jawa. Rancangan percobaan yang digunakan dalam penelitian ini adalah Rancangan Acak Lengkap (RAL) dengan 2 faktorial dan 3 ulangan. Faktor perlakukan pertama yakni bahan perendaman dengan 3 perlakuan yaitu perendaman menggunakan air panas, MSG dan Urin Sapi. Faktor kedua yakni waktu perendaman dengan variasi lama perendaman 6 jam, 12 jam dan 24 jam. Hasil uji daya kecambah benih Kabesak menunjukkan bahwa diperlukan perlakuan awal untuk melunakkan kulit biji Kabesak sehingga proses imbibisi dapat berjalan lebih cepat untuk memacu proses perkecambahan. Perlakuan perendaman dengan air panas menghasilkan daya kecambah tertinggi dibanding perlakuan perendaman dengan bahan lainnya terhadap benih A. leucophloea. Interaksi terbaik untuk bahan perendaman dan lama perendaman terhadap daya kecambah Kabesak yaitu perlakuan perendaman dengan air panas selama 12 jam. Untuk uji daya kecambah Asam jawa diketahui bahwa bahan perendaman tidak mempengaruhi secara signifikan terhadap daya kecambah benih tersebut. Daya kecambah Asam jawa secara signifikan dipengaruhi oleh lama perendaman, perendaman terbaik yaitu selama 6 jam.

\section{Pendahuluan}

Beberapa jenis tanaman asli yang memiliki manfaat penting bagi masyarakat pulau timor antara lain Kabesak (Acacia leucophloea) dan asam jawa (Tamarindus indica). Manfaat dan sifat adaptif yang dimiliki tumbuhantumbuhan ini dapat menjadi alasan untuk menggunakan tumbuhan-tumbuhan ini dalam upaya reklamasi lahan-lahan kering di pulau Timor. Kabesak merupakan salah satu jenis tumbuhan dari family Fabaceae jenis tumbuhan ini memiliki tinggi mencapai $40 \mathrm{~m}$ dengan ukuran diameter mencapai $125 \mathrm{~cm}$ (Hendrik dkk., 2017). Kabesak oleh masyarakat pulau timor dimanfaatkan sebagai bahan konstruksi rumah dan daun Kabesak sebagai pakan ternak di musim kering. Asam jawa merupakan jenis tumbuhan yang memiliki nilai ekonomi bagi masyarakat pulau Timor, buah asam jawa merupakan komoditi hutan yang dapat dijual masyarakat untuk digunakan sebagai bumbu dapur. Kayu asam jawa juga dapat dimanfaatkan sebagai bahan konstruksi maupun kayu bakar. Jenis-jenis tanaman lokal pulau Timor ini masih tumbuh secara liar dan masih sedikit informasi mengenai teknik budidaya yang tepat. Untuk pemanfaatan jenis tanaman ini terutama sebagai tanaman reklamasi perlu pengetahuan mengenai teknik perkecambahan yang tepat. Dengan teknik perkecambahan yang tepat dapat mempercepat produksi semai dan dapat diperoleh semai dengan yang sehat sehingga mampu mendukung keberhasilan program reklamasi baik untuk reklamasi bekas tambang maupun reklamasi lahan kritis (Mansur 2013; Bhatt dkk., 2016). Dalam menyemaikan benih terutama benih tanaman kehutanan terkadang diperlukan perlakuan awal pada benih sebelum menyemaikan. Hal ini dikarenakan benih tanaman kehutanan umumnya mempunyai kulit biji yang keras sehingga diperlukan beberapa teknik perlakuan skarifikasi pada benih untuk mempercepat dan meningkatkan persentase perkecambahan.

Beberapa teknik untuk mempercepat dan meningkatkan persentase perkecambahan benih kehutanan seperti perendaman menggunakan air panas dan urin maupun menggunakan bahan kimia seperti monosodium glutamate (MSG) (Rao \& Sukendro, 2017). Urin sapi dan MSG juga diketahui mengandung senyawa yang dapat mempercepat pertumbuhan tanaman (Dianti \& Sukendro, 2016). Dalam penelitian ini akan dilakukan pengujian metodemetode perlakuan perendaman dalam beberapa bahan dengan variasi waktu tertentu terhadap benih kabesak dan asam jawa sebelum dikecambahkan dan kemudian dilihat daya kecambah benih tumbuhan tersebut. Tujuan dari penelitian ini adalah untuk memperoleh informasi tentang teknik perkecambahan dengan menggunakan bahan perendaman dan waktu perendaman yang menghasilkan daya berkecambah tertinggi untuk beberapa tumbuhan lokal pulau Timor.

\section{Metode}

Bahan yang digunakan dalam penelitian ini adalah benih kabesak dan asam jawa, monosodium glutamat (MSG) 12 gram/liter dengan merek dagang sasa, air, biourine sapi, Natrium hipoklorit dengan merek dagang soklin pemutih, media tanam yaitu pasir dan arang sekam dengan perbandingan $2: 1$. Peralatan yang digunakan selama penelitian berlangsung adalah bak kecambah (seed tray), spayer, desikator, cawan keramik, oven, serta software Microsoft Excel dan minitab 14 untuk pengolahan data.

Benih yang digunakan diambil dari hutan Oesublele, Desa Biloto, Kecamatan Mollo Selatan, Kabupaten Timor Tengah Selatan. Benih yang dikoleksi, dipilih dari pohon induk yang sehat. Benih yang terkoleksi akan disortir dengan melihat perawakan benih yang benih utuh dan tidak berlubang dengan ukuran yang besar atau benih berukuran sedang diantara benih yang disiapkan.

\section{Pembuatan Media Tanam}

Media tanam yang digunakan adalah pasir sungai, dan arang sekam dengan perbandingan $2: 1$ media tersebut dicampur hingga merata kemudian diletakkan ke dalam seed tray.

\section{Sterilisasi Media Tanam}

Sterilisasi dilakukan dengan mengukus media menggunakan natrium hipoklorit 5,25\% yang disemprotkan merata ke seluruh bagian media tanam

\section{Perendaman Benih}

Perendaman benih dilakukan dengan perlakuan antara lain: perendaman menggunakan air panas $1 \mathrm{~L}$ dengan suhu $100^{\circ} \mathrm{C}$, perendaman menggunakan MSG dengan takaran 1 sendok makan MSG seberat 12 gram/liter dan perendaman menggunakan urin sapi $1 \mathrm{~L}$. Waktu yang digunakan untuk merendam benih selama 6 jam, 12 jam dan 24 jam.

\section{Penanaman dan Pemeliharaan}

Penanaman dilakukan pada seed tray yang sudah berisi media tanam berupa pasir, tanah, dan arang sekam yang telah disterilisasi terlebih dahulu, satu buah seed tray berisi 40 benih. Pemeliharaan dilakukan untuk memberikan kondisi yang baik bagi tanaman dalam proses perkecambahan dengan cara penyiraman dan pengendalian hama dan penyakit. Penyiraman dilakukan satu kali sehari yaitu pagi atau sore.

\section{Pengamatan Persentase Kecambah}

Persentase kecambah menunjukkan jumlah kecambah normal yang dihasilkan oleh benih pada kondisi lingkungan tertentu dalam jangka waktu yang telah ditetapkan. Pengamatan persentase kecambah dilakukan selama 30 hari setelah tanam. Cara menghitung persentase kecambah menggunakan rumus berikut (Sutopo,2002)

$$
\text { Daya kecambah }=\frac{n}{N} \times 100 \%
$$

(1)

Keterangan; $n=$ Jumlah Benih yang Berkecembah; $N=$ Total Benih yang Dikembahkan

\section{Rancangan Penelitian}

Rancangan percobaan yang digunakan dalam penelitian ini adalah Rancangan Acak Lengkap (RAL) dengan 2 faktorial dan 4 ulangan. Faktor perlakuan pertama adalah bahan perendaman, factor kedua adalah waktu perendaman yaitu sebagai berikut: $\mathrm{P} 1=$ perlakuan perendaman menggunakan MSG, $\mathrm{P} 2=$ perlakuan perendaman menggunakan urin sapi $20 \%, \mathrm{P} 3=$ perlakuan perendaman menggunakan air panas, $\mathrm{T} 1=$ waktu perendaman $6 \mathrm{jam}, \mathrm{T} 2=$ waktu perendaman $12 \mathrm{jam}, \mathrm{T} 3=$ waktu perendaman $24 \mathrm{jam}$, sehingga tercipta 9 kombinasi perlakuan yaitu P1T1, P1T2, P1T3, P2T1, P2T2, P2T3, P3T1, P3T2, P3T3, dengan 4 ulangan sehingga total unit perlakuan sebanyak 36 unit. Model rancangan yang digunakan adalah sebagai berikut (Mattjik dan Sumertajaya, 2013) 


$$
Y i j=\mu+\alpha i+\beta j+(\alpha \beta) i j+\varepsilon i j k
$$

(2)

Keterangan $: Y i j=$ Nilai pengamatan pada bahan perendaman benih ke-i dan waktu perendaman ke-j, $\mu=$ Rata-rata umur $\alpha i=$ Pengaruh bahan perendaman ke-i, $\beta j=$ Pengaruh waktu perendaman benih ke-j, $\alpha \beta) i j=$ Pengaruh interaksi bahan perendaman ke-i serta waktu perendaman ke-j, $\varepsilon i j k=$ Galat percobaan

\section{Analisis Data}

Analisis data dilakukan menggunakan software Microsoft Excell dan software Minitab 14. Jika P-value $>\alpha(0,05)$ maka perlakuan tidak memberikan pengaruh yang berbeda nyata pada peubah yang diamati. Jika P-value $<\alpha$ $(0,05)$ maka perlakuan memberikan pengaruh yang berbeda nyata pada peubah yang diamati. Uji Fisher dilakukan setelah analisis keragaman berpengaruh nyata. Uji tersebut dilakukan untuk mengetahui perbedaan antar perlakuan.

\section{Hasil dan Pembahasan}

\section{Benih Kabesak dan Asam Jawa}

Benih kabesak dan asam jawa diperoleh dari Hutan Oesublele, Kabupaten Timor Tengah Selatan dan waktu pengambilan benih dilakukan pada bulan September 2017. Kabesak umumnya mulai berbunga pada awal musim hujan berkisar bulan November, dan buah mulai matang pada awal bulan April, sehingga pada waktu pengumpulan benih, biji kabesak telah matang berkisar 4-5 bulan. Hal ini mengakibatkan banyak biji kabesak yang telah mengalami kerusakan pada saat ekstraksi biji, kerusakan yang paling umum ditemui karena adanya serangga pelubang biji yang diduga memanfaatkan kotiledon dari kabesak sebagai sumber makanan. Sebagian biji kabesak yang diekstraksi telah mengalami kerusakan akibat serangan serangga tersebut. Kerusakan pada biji kabesak ini juga diduga mengakibatkan rendahnya biji kabesak yang mampu berkecambah di alam walaupun produksi biji yang tinggi oleh tanaman kabesak. Fakta ini menunjukkan pentingnya upaya budidaya tanaman kabesak di persemaian untuk mendukung penyebaran tanaman penting ini di alam.

Kerusakan pada biji kabesak yang diekstraksi untuk dijadikan benih menyebabkan peneliti perlu melakukan penyortiran terhadap benih yang telah rusak sebelum dilakukan perlakuan perendaman. Penyortiran juga dapat dilakukan setelah perendaman, benih Kabesak yang telah rusak akan mengembang dan lunak akibat banyaknya air yang masuk melalui lubang sehingga mencapai kotiledon biji. Biji tumbuhan asam jawa dibungkus oleh kulit daging buah yang cukup tebal sehingga biji tumbuhan asam cukup terlindungi dari kerusakan. Daging buah asam jawa memiliki nilai ekonomis yang bagi masyarakat lokal di pulau Timor. Buah tumbuhan asam jawa yang telah kering dipanen masyarakat untuk dijual ke pengumpul, sedangkan biji asam jawa oleh masyarakat juga dapat digunakan sebagai pakan ternak babi. Hal ini mengakibatkan penyebaran tumbuhan asam jawa secara alami menjadi terganggu.

\section{Perkecambahan Benih Kabesak dan Asam Jawa}

Perkecambahan merupakan suatu rangkaian proses yang kompleks pada benih dimulai dari proses biokimia, fisiologi dan terjadi perubahan morfologi yang ditandai dengan munculnya radikula ke atas permukaan tanah, pertanda embrio aktif untuk bertumbuh. Menurut Sutopo (2002) tahap pertama suatu perkecambahan benih dimulai dengan penyerapan air oleh benih, melunaknya kulit benih dan hidrasi dari protoplasma. Tahap kedua dimulai dengan kegiatankegiatan sel dan enzim serta naiknya tingkat respirasi benih. Tahap ketiga merupakan tahap terjadi penguraian bahan-bahan seperti kabohidrat, lemak dan protein menjadi bentuk-bentuk yang terlarut dan di translokasikan ke titik tumbuh.

Tahap keempat adalah asimilasi dari bahan-bahan yang telah diuraikan tadi di daerah meristematik untuk mengahasilkan energi bagi kegiatan pembentukan komponen dan pertumbuhan sel-sel baru. Tahap kelima adalah pertumbuhan dari kecambah melalui proses pembelahan, pembesaran, dan pembagian sel pada titik tumbuh. Terdapat 2 tipe perkecambahan yaitu perkecambahan epigeal yaitu posisi daun lembaga pada saat berkecambah muncul di atas permukaan tanah dan perkecambahan hypogeal yaitu posisi daun lembaga tetap berada di bawah permukaan tanah (Tjitrosoepomo 2005) Tipe perkecambahan benih Kabesak dan Asam jawa termasuk dalam tipe perkecambahan epigeal karena posisi daun lembaga berada di atas permukaan tanah pada saat kedua jenis tumbuhan ini berkecambah (Gambar 1 dan Gambar 2). Benih Kabesak dalam penelitian ini mulai berkecambah pada hari ke 6 setelah penanaman yaitu dimulai pada perlakuan perendaman dengan air panas selama 12 jam perendaman. Untuk Benih Asam jawa diketahui mulai berkecambah pada hari ke 11 setelah penanaman yaitu pada perlakuan perendaman dengan MSG selama 12 jam

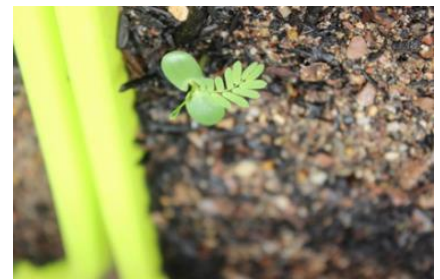

Gambar 1. Semai A. leucophloea

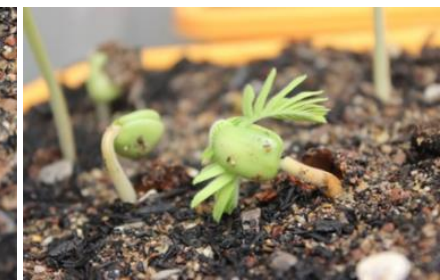

Gambar 2. Semai T. indica
Pengaruh Bahan Perendaman dan Lama Peredaman terhadap Daya Kecambah A. Leucophloea

Untuk melihat pengaruh dari bahan perendaman dan lama perendaman terhadap daya kecambah kabesak dilakukan analisis sidik ragam, dan diperoleh hasil dalam Tabel 1 sebagai berikut :

Tabel 1. Hasil Anova Pengaruh Bahan Perendaman dan Lama Perendaman terhadap Daya Kecambah Kabesak

\begin{tabular}{lcccl} 
Sumber & DB & F & P & Keterangan \\
\hline BahanPerendaman & 2 & 13,32 & 0,000 & signifikan \\
\hline Lama Perendaman & 2 & 3,70 & 0,045 & signifikan \\
\hline Interaksi & 4 & 5,97 & 0,003 & signifikan \\
\hline
\end{tabular}

Berdasarkan hasil Anova diketahui bahwa bahan perendaman berpengaruh terhadap daya kecambah kabesak ( $\mathrm{P}$ value $0,00<0,05)$, lama perendaman juga berpengaruh terhadap daya kecambah tumbuhan kabesak ( $\mathrm{P}$ value $0,045<0,05)$. Hasil Anova juga menunjukkan interaksi antara faktor bahan perendaman dan lama perendaman berpengaruh terhadap daya kecambah benih kabesak ( $\mathrm{P}$ value $0,003<0,05$ ). Adanya pengaruh perlakuan yang signifikan terhadap respons daya kecambah, maka dilakukan uji Fisher untuk melihat perbedaan antara level tiap perlakuan dan interaksi antar perlakuan. Nilai R-Square dari hasil Anova sebesar 76,30 \% menandakan daya kecambah kabesak didapat dijelaskan sebesar 76,30 \% dari nilai faktor bahan perendaman dan lama perendaman. Hasil uji Fisher untuk level perlakuan bahan perendaman ditampilkan pada Tabel 2 .

Tabel 2. Hasil Uji Fisher Pengaruh Level Bahan Perendaman terhadap Daya Kecambah Kabesak

\begin{tabular}{lcc}
\hline Bahan perendaman & N & Rata-rata kelompok \\
\hline Air Panas & 9 & $35,83 \mathrm{~A}$ \\
\hline Monosodium Glutamate & 9 & $19,44 \mathrm{~B}$ \\
\hline UrinSapi & 9 & $15,56 \mathrm{~B}$ \\
\hline
\end{tabular}

Berdasarkan hasil uji Fisher di atas terlihat bahwa daya kecambah kabesak yang direndam menggunakan air panas lebih tinggi dan berbeda nyata dengan bahan perendaman Monosodium Glutamat (MSG) dan urin sapi. Benih kabesak walaupun kecil namun memiliki kulit biji yang keras sehingga perlakuan dengan air panas diduga dapat menyebabkan kulit biji kabesak lebih mudah untuk ditembus air yang memicu benih untuk memiliki daya berkecambah yang tinggi. Perlakuan dengan perendaman dengan MSG dan urin sapi tidak memberikan pengaruh sebaik perlakuan perendaman dengan air panas karena dua perlakuan tersebut diduga tidak mampu untuk menyebabkan air menembus dengan cepat dan mudah melewati kulit biji kabesak yang keras. Menurut Gresinta (2015) MSG memiliki kandungan yang berperan sebagai hormone perangsang tumbuh seperti giberelin, namun hormone tersebut berperan setelah biji berkecambah yang dimulai dari proses imbibisi air. Begitu pula dengan urin sapi yang merupakan limbah hewan ternak yang walaupun memiliki unsur-unsur hara esensial yang diperlukan seperti nitrogen $(\mathrm{N})$, fosfor (P) dan Kalium (K) (Huda dkk., 2013), namun tidak mempercepat proses imbibisi sehingga daya kecambah perlakuan ini lebih rendah dibanding perlakuan perendaman air panas. Kerasnya kulit biji (pericarp) kabesak mengakibatkan perlakuan perendaman air panas lebih efektif untuk mempercepat proses pada tahap pertama perkecambahan benih yaitu mempercepat pelunakan benih sehingga air mudah untuk meresap masuk ke dalam benih. Hal ini menguatkan hipotesis bahwa kulit biji memberi ketahanan mekanis yang menghambat imbibisi benih dan penghambatan kimia seperti yang ditunjukkan pada spesies seperti Diptychocarpus strictus (Lu dkk., 2010) Rapistrum rugosum (Ohadi dkk., 2011), Fortuynia garcinii (Eskandari, 2017) Untuk meningkatkan daya kecambah benih dengan kulit biji yang keras, disarankan penggunaan metode skarifikasi secara mekanik (Febriyan \& Widajati, 2014; Yuniarti dkk., 2013). Hasil uji Fisher untuk level perlakuan lama perendaman ditampilkan pada Tabel 3 .

Tabel 3. Hasil Uji Fisher Pengaruh Level Lama Perendaman Terhadap Daya Kecambah Kabesak

\begin{tabular}{llc}
\hline Lama Perendaman & $\mathrm{N}$ & Rata-Rata Kelompok \\
\hline 12 jam & 9 & $28,06 \mathrm{~A}$ \\
\hline 24 jam & 9 & $25,56 \mathrm{~A}$ \\
\hline 6 jam & 9 & $17,22 \mathrm{~A}$ \\
\hline
\end{tabular}

Berdasarkan hasil uji Fisher terlihat bahwa antara level perlakuan lama perendaman tidak terdapat perbedaan yang signifikan antara setiap level perlakuan. Meskipun nilai rata-rata daya kecambah pada perlakuan perendaman selama 12 jam lebih tinggi dibanding perlakuan 6 jam dan 24 jam namun tidak signifikan perbedaan nilai daya kecambahnya. Meski terlihat bahwa rata-rata daya kecambah pada perlakuan di atas 12 jam lebih tinggi dibandingkan 6 jam, sehingga dapat disarankan untuk menyemaikan benih kabesak perlu perendaman di atas 12 jam untuk memperoleh nilai daya kecambah yang lebih tinggi. Hasil uji Fisher untuk interaksi perlakuan bahan dan lama perendaman ditampilkan dalam Tabel 4. 
Tabel 4. Hasil Uji Fisher Pengaruh Interkasi Bahan Dan Lama Perendaman Terhadap Daya Kecambah Kabesak

\begin{tabular}{llc}
\hline Interaksi & N & Rata-Rata Kelompok \\
\hline Air Panas 12 Jam & 3 & $56,667 \mathrm{a}$ \\
\hline Air Panas 24 Jam & 3 & $27,500 \mathrm{~b}$ \\
\hline MSG 24 Jam & 3 & $25,833 \mathrm{bc}$ \\
\hline UrinSapi 24 Jam & 3 & $23,333 \mathrm{bc}$ \\
\hline Air Panas 6 Jam & 3 & $23,333 \mathrm{bc}$ \\
\hline MSG 6 Jam & 3 & $17,500 \mathrm{bc}$ \\
\hline MSG 12 Jam & 3 & $15,000 \mathrm{bc}$ \\
\hline UrinSapi 12 Jam 3 & 3 & $12,500 \mathrm{bc}$ \\
\hline UrinSapi 6 Jam & 3 & $10,833 \mathrm{c}$ \\
\hline
\end{tabular}

Hasil uji Fisher menunjukkan interaksi perlakuan bahan dan lama perendaman terbaik yaitu bahan perendaman air panas selama 12 jam perendaman. Kombinasi perlakuan ini menghasilkan nilai rata-rata daya kecambah tertinggi dan berbeda nyata dengan kombinasi perlakuan bahan dan lama perendaman lainnya. Kombinasi perlakuan lainnya menghasilkan notasi yang sama sehingga dapat disimpulkan bahwa antar kombinasi perlakuan tersebut tidak berbeda nyata antar satu dengan yang lain

\section{Pengaruh Bahan Perendaman Dan Bahan Perendaman Terhadap Daya Kecambah $T$. Indica}

Hasil anova pengaruh bahan perendaman dan lama perendaman terhadap daya kecambah asam jawa ditampilkan dalam Tabel 5.

Tabel 5. Hasil Anova Pengaruh Bahan Perendaman Dan Lama Perendaman Terhadap Daya Kecambah Asam Jawa

\begin{tabular}{lcccc}
\hline Sumber & DB & F & P & Keterangan \\
\hline BahanPerendaman & 2 & 3,62 & 0,048 & Signifikan \\
\hline Lama Perendaman & 2 & 5,23 & 0,016 & Signifikan \\
\hline Interaksi & 4 & 1,84 & 0,166 & Signifikan \\
\hline
\end{tabular}

Berdasarkan analisis menggunakan anova daya kecambah asam yang diberi perlakuan media (urin sapi, MSG, air panas) dan lama perendaman yang berbeda, jika $f$ hitung untuk media sebesar 3,62 dan nilai $P$ 0,048 artinya bahwa nilai $\mathrm{P}$ (p-value) 0,048 lebih kecil dari nilai alpha 0,05 maka dapat disimpukan bahwa $\mathrm{H} 0$ ditolak dan $\mathrm{H} 1$ diterima, sedangkan untuk perlakuan lama perendaman mendapatkan f hitung 5,23 dengan nilai P 0,016 dengan taraf kesalahan $5 \%$. Artinya bahwa nilai P ( $p$-value) lebih besar dari nilai alpha 0,05 maka H0 ditolak dan H1 diterima. Dari kedua perlakuan tersebut penggunaan media terhadap daya kecambah memiliki pengaruh yang signifikan, sedangkan untuk perlakuan dengan lama perendaman berpengaruh secara signifikan. artinya bahwa ada pengaruh signifkan antara perlakuan menggunakan bahan dan lama perendaman terhadap daya perkecambahan asam. Untuk pengaruh dari interaksi bahan perendaman dan lama perendaman terhadap daya kecambah tidak nyata atau signifikan dilihat dari nilai $\mathrm{P}$ value $0,166>0,05$ Pengaruh level bahan perendaman terhadap daya kecambah dianalisis lanjutan menggunakan uji Fisher Tabel 6.

Tabel 6. Hasil Uji Fisher Pengaruh Level Bahan Perendaman Terhadap Daya Kecambah Asam Jawa

\begin{tabular}{llc}
\hline Bahan Perendaman & N & Rata-rata kelompok \\
\hline Air Panas & 9 & $61.67 \mathrm{~A}$ \\
\hline Monosodium Glutamate & 9 & $60.56 \mathrm{~A}$ \\
\hline Urin Sapi & 9 & $44.17 \mathrm{~A}$
\end{tabular}

Rata-rata nilai daya kecambah berdasarkan bahan perendaman yang digunakan seperti urin sapi, MSG dan air panas dalam uji Fisher menunjukkan tidak ada perbedaan yang signifikan. Hal ini terlihat dari notasi grup yang sama pada setiap level perlakuan. Namun demikian secara empiris daya perkecambahan asam yang paling besar ada pada perlakuan dengan menggunakan bahan perendaman urine sapi dengan rata-rata 61,67\% kemudian diikuti dengan bahan perendaman MSG dan bahan perendaman air panas yaitu masing-masing $60,56 \%$ dan $44,17 \%$. Tidak adanya pengaruh yang signifikan dari level bahan perendaman terhadap daya kecambah Asam jawa dapat dikarenakan kulit biji kabesak yang tidak keras dan tebal sehingga tidak dibutuhkan perlakuan bahan perendaman khusus untuk memacu daya kecambah tumbuhan ini.

Uji Fisher untuk melihat pengaruh level lama perendaman terhadap daya kecambah Asam jawa (Tabel 7). Hasil uji Fisher menunjukkan level lama perendaman 6 jam menghasilkan rata-rata daya kecambah tertinggi dan berbeda nyata dengan level perlakuan perendaman selama 12 jam dan 24 jam. Secara empiris perlakuan dengan lama perendaman antara 6 jam, 12 jam, 24 jam terdapat perbedaan rata-rata daya perkecambahan, daya perkecambahan dengan perlakuan 6 jam lebih besar yaitu dengan rata-rata 68,89 perlakuan perendaman dengan lama 12 jam mendapat nilai rata-rata 50.56 daya perkembahan, sedangkan perlakuan lama perendaman 24 jam mendapat nilai rata-rata 46,96.

Tabel 7. Hasil Uji Fisher Pengaruh Level Lama Perendaman Terhadap Daya Kecambah Asam Jawa

\begin{tabular}{llc}
\hline Lama perendaman & $\mathrm{N}$ & Rata-rata kelompok \\
\hline 6 jam & 9 & $68.89 \mathrm{~A}$ \\
\hline 24 jam & 9 & $50.56 \mathrm{~B}$ \\
\hline $12 \mathrm{jam}$ & 9 & $46.94 \mathrm{~B}$ \\
\hline
\end{tabular}

Benih dengan kulit biji tipis seperti asam jawa dengan lama waktu perendaman yang lebih panjang justru akan menurunkan daya perkecambahan karena benih yang harusnya mengalami imbibisi justru mengalami plasmolisis (Zulkarnain dkk., 2015)

\section{Simpulan}

Hasil uji daya kecambah benih kabesak menunjukkan bahwa diperlukan perlakuan awal untuk melunakkan kulit biji kabesak sehingga proses imbibisi dapat berjalan lebih cepat untuk memacu proses perkecambahan. Perlakuan perendaman dengan air panas menghasilkan daya kecambah tertinggi dibanding perlakuan perendaman dengan bahan lainnya terhadap benih A. leucophloea. Intaraksi terbaik untuk bahan perendaman dan lama perendaman terhadap daya kecambah kabesak yaitu perlakuan perendaman dengan air panas selama 12 jam. Untuk uji daya kecambah Asam jawa diketahui bahwa bahan perendaman tidak mempengaruhi secara signifikan terhadap daya kecambah benih tersebut Daya kecambah asam jawa secara signifikan dipengaruhi oleh lama perendaman selama 6 jam.

\section{Pustaka}

Bhatt, A., Caron, M.M., Verheyen, K., Elsarrag, E., and Alhorr, Y. 2016. Germination and seedling performance of five native legumes of the Arabian Desert. Flora (220) : 125-133.

Dianti, M., dan Sukendro, A. 2016. Pematahan Dormansi dan Respon Pertumbuhan Bibit Kaliandra (Calliandra calothyrsus Meissn.) terhadap Pemberian Pupuk dan Komposisi Media (Skripsi). Bogor : Institut Pertanian Bogor.

Eskandari, B.S., Ghaderian, S.M., Ghasemi, R., dan Schat, H. 2017. Optimization of seed germinationin an Iranian serpentin endemic Fortuynia garcinii. Flora,231,n 38 - 42. http://dx.doi. Org / 10. 1016/ j. flora. 2017.04 .005$.

Febriyan, D.G., dan Widajati, E. 2014. Pengaruh Teknik Skarifikasi Fisik dan Media Perkecambahan terhadap Daya Berkecambah Benih Pala (Myristica fragrans) (Skripsi). Bogor : Institut Pertanian Bogor.

Gresinta, E. 2015. Pengaruh pemberian monosodium glutamat (MSG) terhadap pertumbuhan dan produksi kacang tanah (Archis hypogeae L). Jurnal Exacta. 8(3).208-219.

Hendrik, A.C., Kusmana, C., dan muhdin 2017. Karakteristik Populasi dan Preferensi Ekologis Kabesak (Acacia leucophloea) di Timor barat (Tesis). Bogor : Sekolah Pascasarjana Institut Pertanian Bogor.

Huda, M.K., Latifah., dan Prasetya, A.T. 2013. Pembuatan Pupuk Organik Cair dari Urin Sapi dengan Aditif Tetes Tebu (molasses) Metode Fermentasi (Skripsi). Semarang: Universitas Negeri Semarang.

Lu, J., Tan, D., Baskin, J.M., and Baskin, D. 2010. Fruit and seed heteromorphism in the cold desert annual ephemeral Diptychocarpus strictus (Brassicaceae) and possible adaptive significance. Annals of Botany, 105, 999-1014. doi:10.1093/aob/mcq041

Mansur, I. 2013. Teknik Silvikultur Untuk Reklamasi Lahan Bekas Tambang. SEAMEO BIOTROP. Bogor.

Mattjik, A.A., dan Sumertajaya I.M. 2013. Perancangan Percobaan dengan Aplikasi SAS dan Minitab. Bogor (ID): IPB Press.

Ohadi, S., Mashhadi, H.R., and Tavakol-afshari, R. 2011. Effects of Storage and Burial on Germination Responses of Encapsulated and Naked Seeds of Turnipweed (Rapistrum rugosum) to Light. Weed Science, 59, 483488. DOI: 10.1614/WS-D-10-00153.1

Rao, S., dan Sukendro, A. 2017. Uji Daya Kecambah Benih Kaliandra (Calliandra calothyrsus Meissn.) dengan Perlakuan Waktu dan Bahan Perendaman Serta Media Tanam (Skripsi). Bogor : Institut Pertanian Bogor.

Sutopo, L. 2002. Teknologi Benih. Jakarta (ID): Raja Grafindo Persada..

Tjitrosoepomo, G. 2005. Morfologi Tumbuhan. Yogyakarta (ID): Gadjah Mada University Press

Yuniarti, N., Megawati., dan Leksono, B. 2013. Teknik Perlakuan Pendahuluan dan Metode Perkecambahan Untuk Mempertahankan Viabilitas Benih Acacia crassicarpa Hasil Pemuliaan. Jurnal Penelitian Kehutanan Wallacea, 2(1), 1-11.

Zulkarnain T, Mardhiansyah M, dan Yoza D. 2015. Pengaruh lama perendaman biji sengon (Paraseriethes falcataria) menggunakan air daun sirih (Piper betleLinn.) terhadap kualitas benih. Jurnal Jom Faperta 2(1): 1-7. 